\title{
Perceptions of Policy Duty Bearers on the Inclusive Education Policy for Pregnant Teenagers in South Africa
}

\author{
Tawanda Runhare ${ }^{1}$ and Saloshna Vandeyar ${ }^{2}$ \\ ${ }^{1}$ School of Education, Department of Early Childhood Education, University of Venda, \\ P. Bag X5050, Thohoyandou 9050, Republic of South Africa \\ E-mail: Tawanda.Runhare@univen.ac.za \\ ${ }^{2}$ Faculty of Education, Department of Humanities Education, University of Pretoria, \\ Pretoria, South Africa \\ E-mail: Saloshna.Vandeyar@up.ac.za
}

KEYWORDS Pregnant Teenagers. Inclusive Policy. Duty Bearers. Regular Schools. Key Stakeholders. Perceptions

\begin{abstract}
Post-apartheid, South Africa democratised access to education as enshrined in the country's Constitutional Bill of Rights of 1996. This also includes making education accessible to pregnant teenagers as provided for by other post-apartheid legal provisions that prohibit discrimination in education. This study explored the perceptions of education policy duty bearers on the inclusion of pregnant learners in formal schools. The sample of the study comprised teachers, community representatives in school governing bodies (SGB), and parents of pregnant teenagers at two schools that mainstreamed pregnant learners. Data were analysed using Atlas ti computer package which was programmed to code and quote participants' views. Results of the study revealed that socio-cultural gender ideologies were the more influential variables on participants' negative perceptions towards the inclusion of pregnant learners in regular schools. From the findings, we recommend that comprehensive structures and procedures for policy dialogue and advocacy be established in schools.
\end{abstract}

\section{INTRODUCTION}

It is evident from research that premature pregnancy is one of the reasons for low school completion rate among female students, especially in developing countries (Wilson and Dekker 1999; Gallup-Black and Weitzman 2004; Richter and Mlambo 2005; Bennett and Asseffi 2005; Chigona and Chetty 2007, 2008). One of the interventions for redressing this problem is the inclusion of pregnant and former pregnant teenagers ${ }^{1}$ into formal education (Bayona and Kandji-Murangi 1996; Manzini 2001; Chilisa 2002; Grant and Hallman 2006; Chigona and Chetty 2007, 2008). Accordingly, most United Nations (UN) member states are signatories to international conventions like the Convention on the Elimination of Discrimination against Women (CEDAW), Convention on the Rights of the Child (CRC), Education for All (EFA) and Millennium Development Goals (MDG), which among other objectives; seek to safeguard the right of every person to education (Stromquist 1998; Sadie 2001). Apart from being signatory to these conventions, South Africa designed policy guidelines that direct schools to allow pregnant learners to continue with their education (Department of Education (DoE) 2007). Accor- ding to the policy, school responsibilities include encouraging pregnant learners to continue with schooling; preventing any discrimination against pregnant learners; taking measures against any hate speech against pregnant learners; providing counselling services and academic support during the period of break from school for delivery. Pregnant learners and their parents are tasked to ensure that all school work is done and submitted for marking, and to attend to all the pre- and postnatal procedures as well as baby care responsibilities (DoE 2007).

However, while formal policy measures are in place, the extent to which they are effectively implemented to benefit the affected learners is still subject to speculation because of inadequate feedback from both policy duty and rights bearers. It is not uncommon for policies to be in place while implementers and targeted beneficiaries are not adequately informed and equipped to effect the desired change (Hess 1999; Jansen 2002). In most African states the inclusion of pregnant learners into formal schools is still a new development which is now slowly replacing the common exclusion, suspension and expulsion punitive measures for girls who fell pregnant while at school (Chilisa 2002; Grant and Hallman 2006; Chigona and Chetty 2007, 2008). This study, 
therefore, provides an insight into how the policy of mainstreaming pregnant teenagers in regular schools is perceived by key basic education stakeholders in South Africa.

\section{Feminist Theoretical Framework on Education as a Basic Human Right}

The human rights discourse provides a powerful framework for the analysis of gender inequalities in education because international statutes like the CRC, CEDAW, EFA, MDG, the Nairobi, Dakar and Beijing Platforms for Action (PfA) and Forward-Looking Strategies (FLS), all pronounce education as a basic human right (Bayona and Kandji-Murangi 1996; Chilisa 2002; Stromquist 2005; Subrahmanian 2005). In this regard, UN member states such as South Africa, which consented to international instruments on gender equality, have the obligation to extend equal educational rights to all children, including girls that could fall pregnant before school completion (Leach 2000; Chilisa 2002; Stromquist 2005; Subrahmanian 2005). In this regard, countries that have expulsion policies for pregnant teenagers violate the right of some children to education, and are at risk of missing the EFA and MDG target of achieving universal basic education by 2015 . On the other hand, countries which have continuation or re-entry policies for pregnant teenagers are consistent with the observation of one important basic right for children. However, it is not unusual for policies to be in place while policy duty bearers are not aware of their responsibilities (Hess 1999; Jansen 2002). Jansen (2002) observes that many education policies have been crafted in post-apartheid South Africa without adequately equipping teachers to implement them. This study was undertaken with the assumption that unless all the stakeholders understood and played their responsibilities with regard to the DoE (2007) schoolgirl pregnancy policy regulations, pregnant learners might only have access to education without gaining the expected educational benefits and outcomes.

\section{Background to Intervention Education Policies on Schoolgirl Pregnancy}

Gender equity policies that seek to integrate pregnant and former pregnant teenagers can be traced from the agitation by feminist scholars and activists who called for gender equality in educational provision (Coulter 1999; Wilson and Dekkers 1999). Britain is among the first countries to enact laws that prohibit any form of discrimination against women in education (Ladner 1987; Weiner 1987; Truscott 1994; Wolpe et al. 1997; Coulter 1999; McGaha-Garnett 2007). The British Education Act of 1944 enshrined the principle of equal opportunity in education by making basic education free and compulsory for every child. The Act makes it legal for pregnant teenagers to attend school (Truscott 1994; Coulter 1999; Stromquist 1999).

In the United States of America (USA), the right of pregnant learners to continue education is based on two acts of parliament which all American states and districts are compelled to adopt and implement in their schools. By the Educational Amendments Act of 1972, referred to as Title IX and the Women's Educational Equity Act (WEEA) of 1975, any discrimination against pregnant teens in schools is prohibited (Ladner 1987; Weimer 1987; Key et al. 2001; McGaha-Garnett 2007). According to McGahaGarnett (2007:15), in the USA, "Teen parents are mandated to attend school (despite circumstances) and are prosecuted/fined when unexpected absence become problematic."

With the ratification of international conventions that call for gender equity in education, some African countries like Botswana, Malawi, Zimbabwe, Namibia, and Cameroon have come up with national policies that protect pregnant teenagers from being discriminated against in education (Manzini 2001; Chilisa 2002; Grant and Hallman 2006; Hubbard et al. 2008). In South Africa, the policy that allows pregnant and former pregnant learners to continue with their education came in place soon after the achievement of democracy in 1996 (Manzini 2001; Kaufman et al. 2001; Grant and Hallman 2006). This democratisation of education has resulted in the increase in population of pregnant learners into South African regular schools (Blaine 2007; Booi 2007; Pandor 2007). However, no research has been undertaken to specifically evaluate how education stakeholders conceptualise and perceive the inclusive education policy for pregnant teenagers.

\section{Study Objectives}

In view of the important role school management, teachers and parents play in policy 
implementation, the main objective of this study were to:

- Evaluate the knowledge base of key education stakeholders on the policy that allow for the inclusion of pregnant girls in ordinary schools.

- Identify positive and negative perceptions on the inclusion of pregnant teenagers into ordinary schools.

- Explain the challenges and prospects for the effective inclusion of pregnant teenagers into formal schools.

\section{METHODOLOGY}

The study employed the qualitative case study methodology to investigate the underlying factors to school based policy duty bearers' conceptualisation of the policy that seeks to redress the school dropout by pregnant girls in South Africa. Berg (2001: 333) is of the view that "the case method is an extremely useful technique for researching relationships, behaviours, attitudes, motivations, and stressors in organizational settings". It was therefore the search for explanations to why and how policy decisions were made, communicated and implemented in schools which made the case study relevant to this study. Further, because people's values and attitudes can best be captured during an interaction process, interactive strategies in the form of focus group interviews were employed to capture data from the participants in their own narratives, meanings and perspectives (Casey 1996; Nyarawanda 2003; Moss 2004).

Two secondary schools that enrolled pregnant learners were selected for an in-depth exploration of the attitudes of education stakeholders towards the inclusive policy for pregnant learners in formal education (Yin 1994; Berg 2001; Merriam and Associates 2002; Hanock and Algozzine 2006; Creswell 2007). At the two schools, study participants were purposively selected (Merriam and Associates 2002; Lemmer and Van Wyk 2004; McMillan and Schumacher 2006) because they were policy duty bearers who were assumed to be knowledgeable on policy measures for mainstreaming of pregnant learners in regular schools. The sample at each school included six teachers in school management and who taught Life Orientation, six parents and six community representatives on the school governing body. Data trustworthiness (Lincoln and Guba 1985;
Moss 2004; Lietz et al. 2006) was achieved by conducting separate focus group interviews for the three categories of participants at each school. Further, at the end of each interview, the participants had the opportunity to verify the accuracy of their quoted statements by listening to their tape recorded focus group discussion.

\section{Data Analysis}

The study generated narrative qualitative data which were meant to explore the meanings that the participants of the study held on the policy of mainstreaming pregnant learners in formal education. The views of the participants were presented in the form of narrative verbatim accounts in order to capture their social construction of meaning from their own perceptions and experiences (Lincoln and Guba 1985; Clandinin 1989; Lemmer and van Wyk 2004). Content, hermeneutic and discourse data analysis and interpretation (Berg 2001; Stemler 2001; Babbie and Mouton 2004; Babbie 2007) were applied by arranging the participants' views into themes, quotations, codes, and memos which emerged from Atlas ti computerised data analysis package (Smit 2001, 2002).

We further employed frequency counting of data codes (Babbie and Mouton 2004) to compare the frequency of participants' thematic views on the inclusive education policy for pregnant teenagers. Table 1 presents a summary of the frequency count on participants' views.

Table 1: Code frequency count

\begin{tabular}{lc}
\hline Code & Frequency \\
\hline Inadequate knowledge of policy & 26 \\
Separate schools & 20 \\
Gender bias & 17 \\
Negative labelling & 16 \\
Teenage sexual immorality & 14 \\
Increase in teen pregnancy & 14 \\
Right to education & 13 \\
School indiscipline & 11 \\
Declining in education & 11 \\
Teenage morality & 6 \\
Gender equality & 3 \\
\hline
\end{tabular}

\section{RESULTS}

Three themes emerged from gathered data. These themes were further subdivided into 
categories or sub-themes. We further broke down the categories into codes, in order to present and analyse the views of the participants in line with the identified themes and categories. Participant narratives, in the form of Atlas ti processed quotations illustrated how the different participants conceptualised the issues that emerged on each of the three themes. Table 2 summarises the themes and categories that emerged from gathered data.

Table 2: Emerging themes and categories

\begin{tabular}{|c|c|}
\hline Theme & Categories \\
\hline $\begin{array}{l}\text { 1. Duty bearers' } \\
\text { knowledge on } \\
\text { inclusive educa- } \\
\text { tion policy for } \\
\text { pregnant teenagers. }\end{array}$ & $\begin{array}{l}\text { 1.1 Inadequate policy } \\
\text { dialogue. }\end{array}$ \\
\hline $\begin{array}{l}\text { 2. Positive views to } \\
\text { policy on inclusive } \\
\text { education policy } \\
\text { for pregnant } \\
\text { teenagers. }\end{array}$ & $\begin{array}{l}\text { 2.1 Policy as } \\
\text { fulfilment of universal } \\
\text { right to education. } \\
\text { 2.2 Policy as } \\
\text { instrument for } \\
\text { gender equity in } \\
\text { education. } \\
\text { 2.3 Policy as avenue } \\
\text { for upholding teenage } \\
\text { morality. }\end{array}$ \\
\hline $\begin{array}{l}\text { 3. Negative discourses } \\
\text { to inclusive } \\
\text { education policy } \\
\text { for pregnant } \\
\text { teenagers. }\end{array}$ & $\begin{array}{l}\text { 3.1 Policy as cause of } \\
\text { increase in teenage } \\
\text { pregnancy } \\
\text { 3.2 Policy as cause of } \\
\text { learner indiscipline. } \\
\text { 3.3 Policy as cause of } \\
\text { declining educational } \\
\text { standards }\end{array}$ \\
\hline
\end{tabular}

\section{Duty Bearers' Knowledge on Inclusive Education Policy for Pregnant Teenagers}

This theme outlines the study participants' conceptualisation of the DoE (2007) policy guidelines on management of pregnant learners. Focus group discussions indicated that policy duty bearers at both study sites had not been formally informed about the policy guidelines on inclusion of pregnant learners in regular schools. Teachers said they were aware of the policy from mere observations that pregnant learners were not expelled from school. This is illustrated by one female teacher, who indicated that:

I have heard about it that learners are allowed to continue when they are pregnant, but I haven't seen where it is documented (Female teacher 2, school 1) P 2: F.G. Interview. doc - 2:1 (4:4) Codes: (Inadequate knowledge of policy).
Further evidence that teachers were not sure about the provisions of the policy was revealed by a male teacher, who added that:

I do not know whether there is a policy or not because I have not seen it, but it is said that the girls who are pregnant must be allowed to come to school. I think we are implementing it since they are not expelled like before (Male teacher 2 , school 2) P 2: F.G. Interview.doc - 2:18 (33:33) Codes: (Inadequate knowledge of policy).

That teachers did not have detailed information on the policy implies that they would not be able to render adequate assistance to pregnant learners because they would not be well informed about their responsibilities as outlined by the policy guidelines. Data from study participants further revealed that there was a direct relationship between inadequate conceptualisation and inadequate dialogue on policy related issues at both schools.

\section{Inadequate Policy Dialogue}

Policy dialogue is an important means of ensuring that policy duty bearers and beneficiaries understand their rights and responsibilities. At both schools, it emerged that school administration neither formally discussed nor informed other stakeholders about policy provisions on inclusion of pregnant learners in regular schools.

As part of school administration representing learners, teachers and the community, SGB members are expected to be informed about school policies (South African Schools Act 1996). At both schools, members who represented parents in the school administration revealed that they had not discussed the schoolgirl pregnancy policy with the school management. Like the teachers, they also knew only the basic principle that pregnant learners should not be expelled from school. This was summed up by one of the SGB members who illustrated lack of policy dialogue by indicating that:

We have not ever discussed this policy and what to do with the pregnant learners in the meeting. We only know that they are allowed to come to school and they should not be expelled (Male SGB member 3, school 1). P 1: F.G. Interview. doc - 1:8 (9:9) Codes: (Inadequate knowledge of policy)

Since the policy had direct effect on their daughters, it is expected that parents of pregnant 
learners are informed about the conditions under which their daughters are enrolled in regular schools. However, from what the parents said, it appeared that nothing substantial was explained to them by school management. This is represented by one parent who indicated that she was prepared to discuss any problem with school management, but had not been given this opportunity when her daughter fell pregnant. She seemed to regret that:

...we were not called to school to discuss that our daughter is now pregnant.... May be they can call us if she causes a problem at school or if she is sick (Female parent 5). P 3: F.G. Interview. doc - 3:30 (48:48) Codes: (Inadequate knowledge of policy)

From what the teachers, parents and members of school governing bodies said, it appears that policy matters are largely a preserve of top school management as there is no formal consultative process on policy related issues at both schools.

\section{Positive Views to Inclusive Education Policy for Pregnant Teenagers}

Data from this study revealed that the major perceptions to the inclusion of pregnant teenagers into regular schools had two categories, namely the positive and negative responses. In this theme, we report on three categories which illustrate the views that were expressed by study participants in support of the national policy guidelines on mainstreaming of pregnant learners in formal schools. Some participants expressed positive views basing their argument on the premise that education is a basic human right and that inclusion of pregnant teenagers in schools promoted principles of gender equality. There were, however, two categories of those who supported the policy as promotion of the basic right to education. One group gave unreserved support for the policy and argued that pregnant teenagers should have equal educational rights just like any other child. The second group argued that while every child should have the right to education, this right should only be extended to responsible children.

\section{Policy as Fulfilment of Universal Right to Education}

Most participants at both study sites, irrespective of gender, felt that the policy that allowed pregnant learners to continue with schooling promoted the principle of education as basic right for all children. Some parents argued that education is important for pregnant learners because it would allow them to be independent even if they remained single mothers. This common view is represented by one female parent who argued that educated single women do not depend on social grants from the government because:

...if we leave these girls from going to school, we are building more problems for the country because they become beggars and prostitutes. If you look at educated women, they have no problem even if they are not married (Female parent 3, school 2). P 3:F G Interview.doc - $3: 3$ (14:14) Codes: (Gender equality)

However, others were of the view that while the policy benefited the pregnant girls, it had some negative consequences on mainstream learners. Although in support that the policy is an important avenue to realisation of equal right to education, these others were concerned that:

Everyone is just following the policy because everyone has the right to be educated in this country. This is why we never discuss this policy in schools; whether it is the best for other children who are not pregnant (Male SGB member 1, school 1). P 1: F.G Interview.doc 1:12 (11:11) Codes: (Right to education)

This sentiment also revealed that the policy might have been formulated without wide consultation with stakeholders at the school level. A top to down approach to policy formulation is common in most formal organisations.

\section{Policy as an Instrument for Gender Equity}

Some participants at both study sites added the dimension of gender equity to their perception of the inclusive education policy for pregnant learners. Most of these were female policy duty bearers who argued that the inclusion of pregnant teenagers in formal schools is an important gender equity measure. Views expressed touched on issues like the need to improve women's lives, the disadvantaged plight of women in education and employment, education as a means of reducing prostitution, gender bias and the need to free women from the home and child care responsibilities. The women further argued that some men opposed 
the policy because, unlike women, most men do not experience being sexually abused. The support to the policy as a gender equity measure is illustrated by one SGB female representative who complained that:

If it were men who are affected and are to be expelled from school, you will find that most men would support it. But just because it's us women; then men just oppose it without fairness. This is why the minister supports it; she knows what we go through as women. These girls, otherwise it's not their fault but men have abused them (Female SGB member 1, school 2) P 1: F.G. Interview.doc 1:15 (16:16) Codes: (Gender bias).

This submission called for equal treatment of both the pregnant girl and the male partner responsible for the pregnancy. Furthermore, most female participants at both schools saw the policy of mainstreaming pregnant teenagers in school as a means of redressing gender imbalances in education and employment. This is illustrated by a female parent who supported the policy because it economically empowered women. She argued that educating women benefited society at large because:

It's better if the mother is educated. Many single mothers are looking after their children without the help of any man. Let us give these women a chance because they say if you educate a woman you have educated the nation (Female parent 2, school 1) P 3: F.G. Interview.doc - 3:1 (13:13) Codes: (Gender equality).

These statements illustrated that some of the policy duty bearers are aware that education is one of the basic human right which should be accessed by all children, including those who could fall pregnant before completing their education.

\section{Policy as an Avenue for Upholding Teenage Morality}

Arguing from a moral point of view, some of the participants supported the mainstreaming of pregnant learners in formal schools because it protected pregnant teenagers from social pressure that could lead to abortions and suicide. Participants at both study sites blamed parental pressure for teenage baby dumping, abortions, prostitution and suicides. According to one teacher, such pressure could lead to serious problems because: ...some of the parents are unable to help their kids, you see them chasing them away from their homes, and they end up in streets. Some just kill the babies and dump them in dustbins (Female teacher 4. School 1) P 2: F.G. Interview.doc 2:36 (74:74) Codes: (Teenage morality).

\section{Negative Discourses to Inclusive Education Policy for Pregnant Teenagers}

We identified three main arguments that were opposed to the inclusion of pregnant learners in formal schools, namely that the policy could be the cause for the increase in teenage pregnancy, school indiscipline and poor educational standards in schools. Most of the participants were, therefore, of the view that pregnant teenagers should be enrolled in special schools where they may not 'socially contaminate' other children:

If I were the minister of education, I would find a centre within every circuit which would cater particularly for pregnant learners and those with babies. Such a school should have a very low enrolment... (Female teacher 3, school 2) P 2: F.G. Interview.doc - 2:3 (101:101) Codes: (Separate schools)

This view was expressed by those who though that separation would also help to destigmatise and teach the affected learners life skills during the period of pregnancy. After delivery, they could then return to the regular school and resume their normal academic pursuit.

\section{Policy as Cause of Increase in Teenage Pregnancy}

Most participants, irrespective of gender and study sites believed that mixing pregnant learners with their mainstream counterparts could make teenage pregnancy to become an infectious social problem. Both teachers and SGB members at both schools blamed the inclusion of pregnant learners in regular schools as a causal factor for the increase in teenage pregnancy in schools. They argued that the inclusive policy is like rewarding bad behaviour, which encouraged children to experiment with sex. As an illustration of this view one of the teachers complained that:

...it is unnecessary that girls who are pregnant must continue with schooling because 
it makes other girls to also want to try and see what happens when you are pregnant because they take it like others who are pregnant are given privileges (Female teacher 4, school 2) P 2: F.G. Interview.doc - 2:20 (39:39) Codes: (Increase in teen pregnancy).

Congruent to the teacher's view is a concern raised by one SGB member who expressed the commonly held perception that:

...more and more girls become pregnant. They don't see anything wrong with it because they are given a reward of going to school and the child grant ${ }^{2}$. (SGB male member 1, school 2). P 1: F.G. Interview.doc - 1:14 (15:15) Codes: (Increase in teen pregnancy)

There were concerns by most teachers and SGB representatives that some parents did not closely monitor their daughters' behaviour because of the monetary benefits that are linked to child bearing in South Africa.

\section{Policy as Cause of Learner Indiscipline}

Related to the claim that mainstreaming pregnant learners at formal schools was a cause of increased teenage pregnancy, some of the participants expressed concern that it also caused indiscipline in schools. Parents and teachers claimed that pregnant learners are generally difficult to discipline both at home and at school. This view is illustrated by the claim that:

If you find a girl getting pregnant, that girl is stubborn even at home to her parents. They will have failed to control her... and we hear that they even challenge teachers (Female parent 3, school 2) P 3: F.G. Interview.doc - 3:6 (18:18) Codes: (Negative labelling).

Teachers at both schools concurred with parents by labelling pregnant learners as failures because they had lost direction and were difficult to discipline. A common allegation from the teachers was that:

Most of these girls who become pregnant will fail school anyway because they are the stubborn ones; so to go to their home and try to help them is a waste of time (Male teacher 3, school 1). P 2: F.G. INTERVIEW.doc - 2:24 (62:62) Codes: (Negative labelling)

It was further alleged by most teachers that pregnant learners are difficulty to discipline because they take advantage of their health condition due to the understanding that:
... the teacher will not do anything to them; some you see they sleep while you teach, and we just leave them like that because if you threaten them and they develop complications, you get into problems with the law (Male teacher 3, school 2) P 2: F.G. Interview.doc 2:24 (48:48) Codes: (School indiscipline).

\section{Policy as Cause of Declining Educational Standards}

Besides being blamed for causing increased teenage pregnancy and indiscipline in schools, participants from both study sites expressed concern that mainstreaming pregnant learners at formal schools caused poor educational standards. It was claimed that pregnant learners do not focus on their education, had divided attention and lacked concentration on academic issues. It was further claimed that the mere presence of pregnant learners in a school could make the school lose its status in the community, because pregnant teenagers are negatively perceived and labelled as social failures. Most community representatives in SGB claimed that there is usually a correlation between enrolling pregnant learners and poor academic performance at a school. The claim was based on the observation that:

If you check you find that the schools with such girls do not even perform well (Female SGB member 3, school 1) P 1: F.G. Interview.doc - 1:3 (5:5) Codes: (Decline in education).

To illustrate the opposition to the policy of enrolling pregnant learners, another SGB representative cited a school that maintained good educational standards by pointing out that:

If you go to $\mathrm{Mbilwi}^{3}$, do you think you will find any pregnant girl there? Or private schools where people with money send their children.... We cannot maintain good standards at a school if learners are mixing with people in maternity.... This thing is killing education (Male SGB member 1, school 2) P 1: F.G. Interview.doc 1:2 (5:5) Codes: (Decline in education).

Most participants expressed that allowing pregnant and former pregnant teenagers to enrol at formal schools could be detrimental to the reputation of the school in the community.

\section{Codes Frequency Count on Data}

It was not possible to cite all statements made by participants in this report. Table 1 gives a 
summary of data codes that emerged from quotations that were processed using the Atlas ti data analysis software. The frequency represents the number of times the code was generated from the participants' quoted statements. In compiling the table, we considered whether the code represented a positive or negative perception to the policy of mainstreaming pregnant learners in formal education. The table indicates that inadequate knowledge of policy, call for separate schools and gender bias were the more frequent codes. From the table, we concluded that these were the three more influential governing variables to the attitudes and responsiveness of study participants towards the policy of mainstreaming pregnant teenagers in formal education. Our analysis of the quotations which were linked to the generated codes revealed that with the exception of policy as promotion of equal right to education, teenage morality and gender equality, and opposition to gender bias, most of the statements portrayed negative attitudes to the inclusive education policy for pregnant teenagers. We therefore concluded that there were more challenges to the inclusion of pregnant teenagers in formal schools. However, we considered the few positive categories to be an indication that there were opportunities for schools to become more sensitive to the educational needs of teenagers who could fall pregnant while at school.

\section{DISCUSSION}

Data from the study indicated that there were three major variables that influenced education stakeholders and policy duty bearers' attitudes and responses to the inclusion of pregnant learners in ordinary schools, namely the level of conceptualisation of school policy which allows and regulates the enrolment of pregnant teenagers into formal schools, socio-cultural values and attitudes on teenage pregnancy or single motherhood, and the influence of gender inequality in society.

\section{Inadequate Policy Conceptualisation}

One of the objectives of this study was to investigate policy duty bearers' conceptualisation of the policy that provides for the inclusion of pregnant learners in formal education. The policy outlines the different responsibilities of school management, teachers and parents in instituting intervention measures that aim to help enrolled pregnant and former pregnant learners to be accommodated, adjusted and actively participate in all curricular activities (DoE 2007). The study was, therefore, conducted on the assumption that teachers, school principals, community representatives in the School Governing Body (SGB) and parents of the enrolled pregnant or former pregnant learners were informed about the main policy provisions of this policy. Narratives from all the three categories of policy duty bearers who participated in this study revealed that there was no formal dialogue to educate stakeholders on the policy that allowed pregnant learners to be enrolled at formal schools. The study participants were only aware that pregnant learners had the legal right to continue with schooling through mere observation or the custom and practice that pregnant girls were not expelled from school by school management. Teachers lacked basic skills to counsel and guide the affected, as well as the mainstream learners with coping strategies. Consequently, the study revealed that pregnant learners were not given meaningful attention and assistance in the school. For example, there were no separate progress records on pregnant learners and most teachers had no particular information on learners who were either currently pregnant or had given birth at the time when the study was conducted. Unless something needed to be attended to with regards to their children's pregnancy while at school, there was no formal dialogue between parents of pregnant learners and school management. Overall, it was concluded from the study that the policy duty bearers at both schools could not shoulder their responsibilities in managing learner pregnancy related problems within the school because they had inadequate knowledge on what is expected of them in terms of the stated national policy guidelines on the prevention and management of school girl pregnancy (DoE 2007; Runhare 2010).

From what the teachers, parents and community representatives in the SGB said, it appears that since there was no formal consultative process on policy related issues at both schools, policy matters were therefore largely a preserve of principals or top school management. This observation concurs with earlier 
studies by Lemmer and Van Wyk (2004), Mncube (2007) and Mncube and Harber (2009), whofound that parents and learners in South African SGBs did not have much say on policy issues, and that the decision-making was therefore largely centralised in the hands of school principals. However, the fact that participants of this study were aware that policy prohibited the expulsion of pregnant girls from school is an opportunity to assist schools in developing school-based policy guidelines to identify and cater for the educational needs of learners who could fall pregnant while at school. This is in line with international conventions like EFA, MDG, CRC, CEDAW and the South African Constitution's Bill of Rights which all define education as a basic human right for all people irrespective of their different circum-stances (Daniel 2003; Tsanga et al. 2004; Stromquist 2005; Subrahmanian 2005).

\section{Oppositional Discourse to Policy}

One common observation from the study sites was opposition which the policy of enrolling pregnant learners in regular schools received from most of the study participants. The policy was blamed for being too permissive with children, and the increase in teenage pregnancies, school indiscipline and low quality of education at schools, were therefore mainly attributed to it. The concern that the policy was too permissive and therefore encouraged teenagers to become pregnant as a way of accessing social grants was found not to be an isolated view. There are claims that the higher rate of teenage pregnancy in poor urban and rural South African communities is attributed to girls seeking to access child grants as a source of financial subsistence (Kaufman et al. 2001; Manzini 2001; Human Sciences Research Council (HSRC) and Education Policy Consortium (EPC) 2005). Review of other related studies has indicated that there is a correlation between poverty and teenage pregnancy (Brindis and Philliber 1998; Arai 2003; Jackson and Abosi 2007). In South Africa, there are indications that there is a high rate of teenage pregnancy among low income social groups and that unemployed single mothers were more dependent on social grants (Kaufman et al. 2001; Manzini 2001; Human Sciences Research Council (HSRC) and Education Policy Consortium (EPC) 2005).
The study further revealed that, because of engendered cultural values on marriage and single motherhood, most participants complained that the inclusion of pregnant learners in regular schools was like rewarding immoral teenage sexual behaviour. This finding is not an isolated phenomenon to South African school communities and education stakeholders. A survey of how the enrolment of pregnant learners was viewed by communities and district education administrators in America also revealed that school teachers and principals felt that schools should not be in business of caring for babies and pregnancies (Ladner 1987; Weiner1987). Research findings by Bayona and KandjiMurangi (1996), Meekers and Ahmed (1999), Chilisa (2002), and Hubbard et al. (2008) also concurred that communities in Botswana perceived the policy on re-enrolment of former pregnant teenagers into formal schools as culturally unacceptable. Data from the current study therefore also indicate that cultural taboos on sexually and reproductive health in African communities (Chiroro et al. 2002; Jackson 2002; Richter and Mlambo 2005) still militate against educational access and participation by pregnant and former pregnant teenagers.

\section{Liberal Discourse to Policy}

However, from the views expressed by some of the participants of this study, it would appear that although there were more negative sentiments against the inclusion of pregnant learners in ordinary schools, there was an acknowledgement that pregnant teenagers had the right to education. The espoused theory which made some of the participants to acknowledge that pregnant learners should have equal rights in education seemed to arise from human rights and gender equity principles. This was based on the perception that the policy can help to achieve gender equality in society, and that educated girls can be financially independent than depend on social grants, and cannot be sexually abused. These positive revelations from the respondents of this study indicated that the right to education could be a platform upon which inclusion of pregnant learners at formal schools can be advocated. This entails that education stakeholders at school level, should be assisted to identify and critique sociocultural factors that could be obstacles to all 
children, including pregnant teenagers' equal right to education.

Some participants at both study sites strongly presented the dimension of gender equity to their perception of the inclusive education policy for pregnant learners. Most of these were female policy duty bearers who argued that the inclusion of pregnant teenagers in formal schools is an important gender equity measure. We put these views in their own category because they were in line with international conventions like CEDAW, CRC, EFA and MDG, which call for equal educational access and participation by all children regardless of gender or any other differences (Daniel 2003; Tsanga et al. 2004; Stromquist 2005; Subrahmanian 2005). Such submissions called for the equal treatment of both the pregnant girl and the male partner responsible for the pregnancy. It was pointed out by some of the female participants that it was uncommon for the pregnant girl child to lose her educational access and opportunity while nothing was done to the boy or man who impregnated the girl. Research from elsewhere indicated that one major weakness in the implementation of schoolgirl pregnancy policies in most African societies is the usual unfairness of only punishing the pregnant partner (Bayona and Kadji-Murangi 1996; Chilisa 2002; Gordon 2002; Hubbard et al. 2008).

From a moral point of view, another argument which was forwarded in support of accommodating pregnant teenagers in formal education was that it could prevent abortions and suicide. According to this view, most of the teenagers ended up aborting, throwing their babies into dust bins, or committing suicide due to pressure from society against teenage pregnancy. This is collaborated by some research findings which indicated that teenage pregnancy is usually accompanied by psycho-social problems like depression, stress, hypertension, isolation and suicidal tendencies (Ritcher and Mlambo 2005; Jackson and Abosa 2007; Miller et al. 2008). Putting in place rehabilitating interventions like systemic counselling and continued schooling could save teenagers from such detrimental emotions.

We interpreted these mixed views to the inclusive policy for pregnant teenagers to match what Kelly (1998) and Burdell (1998) termed conservative and liberal discourses which were found among teachers at schools that had programmes for pregnant teenagers in the USA. They observed that on the one hand, conservative teachers were against the inclusion of pregnant teenagers in regular schools because they 'polluted' other students by showing off with their babies. Liberal teachers, on the other hand, insisted that schools should cease to be regarded as privileged institutions that only served a homogenous group of children (Weiner 1987; Burdell 1998; Kelly 1998).

\section{CONCLUSION}

This study revealed that one reason for the ineffective policy implementation is the inadequate knowledge and appreciation of the inclusive education policy for the inclusion of pregnant teenagers in regular schools. Despite the acknowledgement that pregnant teenagers had the right to education, it would appear from this study that the negative perceptions towards the inclusion of pregnant learners in regular schools originate from the socially constructed negative labelling of single motherhood and gender bias. Thus, while pregnant teenagers have legal access to schooling, this study revealed that they might not access the rights within and through education unless teachers, principals and parents as key policy duty bearers changed their attitudes and get empowered to identify, appreciate and cater for the educational needs of teenagers who could fall pregnant while at school.

\section{RECOMMENDATIONS}

In view of the high prevalence of teenage pregnancy in South Africa, and since education is a basic human right, we conclude this study with recommending the following:

- There is need to re-examine certain culturally engendered beliefs, norms and values on pregnancy, marriage and single motherhood, that are harmful to gender equality in education and other public spheres.

- Formal schools should be helped to redefine and broaden their pastoral roles so as to identify and accommodate the needs of different children, including those who might fall pregnant while at school.

- Due to poor policy conceptualisation by stakeholders at both schools, an allinclusive consultative policy formulation and implementation process, involving 
learners, teachers, principals and the broad spectrum of the community should be undertaken at the school level.

- Schools should track, monitor and keep progress records of pregnant and expregnant learners, during and after pregnancy in order to assess how such learners are benefiting from educational access.

- There should be pre- and in-service training of teachers on basic counselling skills to empower them on handling teenage pregnancy.

- Finally, teenage pregnancy should be included as one of the contemporary issues for teacher education curriculum in the country.

\section{REFERENCES}

Arai L 2003. British policy on teenage pregnancy and childbearing: The limitations of and comparisons with other European countries. Critical Social Policy, 23(1): 89 -102.

Babbie E, Mouton J 2004. The Practice of Social Research. Oxford: Oxford University Press.

Bayona ELM, Kandji-Murangi I 1996. Botswana's Pregnancy Related Educational Policies and their Implications on Former Pregnant Girls' Education and Productivity: Research Report No. 16. Nairobi: Academy Science Publishers.

Berg BL 2001. Qualitative Research Methods for the Social Sciences. Nedham Heights: Allyn and Bacon.

Blaine S 2007. Investigate Schoolgirl Pregnancies. Business Day, $6^{\text {th }}$ March, P. 4.

Booi M 2007. Sorry Teacher, I Can't Write Exams, I'm Having a Baby. Daily Dispatch, $9^{\text {th }}$ March, P. 3.

Brindis C, Philliber S 1998. Room to grow: Improving services for pregnant and former pregnant teenagers in school setting. Education and Urban Society, 30(2): 242-260.

Casey K 1996. The new narrative research in education. Review of Research in Education, 21: 211-253.

Chigona A, Chetty R 2008. Teen mothers and schooling: Observations from two case studies. South African Journal of Education, 28(2): 261- 281.

Chigona A, Chetty R 2007. Girls education in South Africa: Special consideration to teen mothers as learners. Journal of Education for International Development, 3(1): 1-17.

Chilisa B 2002. National policies on pregnancy in educational systems and sub-saharan africa: The case of Botswana. Gender and Education, 14(1): 21-35.

Chiroro P, Mashu A, Muhwava W 2002. The Zimbabwean Male Psyche with Respect to Reproductive Health, HIV, AIDS and Gender Issues. Harare: UNFPA (United Nations Population Fund) and Centre for Applied Psychology.

Coulter RP 1999. Doing Gender in Canadian Schools: An Overview of the Policy an Practice Mélange.
In: Eiskine S, Wilson M (Ed.): Gender Issues in International Education: Beyond Policy and Practice. New York: Flamer Press, pp. 113-129.

Creswell JW 2007. Research Design: Qualitative and Quantitative Approaches. London: SAGE Publication.

Daniel J 2003. Education For All in The Commonwealth: What Are the Issues? In: Brown L (Ed.): Education in the Commonwealth: The First 40 Years. London: Commonwealth Secretariat.

Department of Education 2007. Measures for the Prevention and Management of Learner Pregnancy. Pretoria: Department of Education.

Gallup-Black A, Weitzman BC 2004. Teen pregnancy and urban youth: Competing truths, complacency and perceptions of the problem. Journal of Adolescent Health, 34(5): 366 - 375.

Gordon R 2002. A Preliminary Investigation of the Causes and Consequences Of School Girl Pregnancy and Dropout in Zimbabwe. Harare: Department for International Development (DFID).

Grant M, Hallman K 2006. Pregnancy-related School Dropout and Prior-School Performance in South Africa: Policy Research Session Working Paper No. 212. New York: Population Council.

Hess F 1999. Spinning Wheels: The Politics of Urban School Reform. Washington DC: Brookings Institution Press.

Hubbard D, Munyinyi W, Eggerman HB, Schulze-Allen M, Carew-Watts, A, Holt J, Coomer R, Van Wyk S, Schmidt M, Zimry C, Barth K 2008. School Policy on Learner Pregnancy in Namibia: Background to Reform. Windhoek: Gender Research and Advocacy Project Legal Assistance Centre.

Human Sciences Research Council (HSRC) and Education Policy Consortium (EPC) 2005. Emerging Voices: A Report on Education in South African Rural Communities. Cape Town: HSRC Press.

Jackson H 2002. AIDS Africa: Continent in Crisis. Harare: (Southern African HIV/AIDS Information Dissémination Services) SAfAIDS.

Jackson K, Abosi O 2007. Some common stressors for African women. E-Journal of Applied Psycho$\log y, 3(1): 34-42$.

Jansen JD 2002. Political symbolism as a policy craft: Explaining non-reform in South African Education after apartheid. Journal of Educational Policy, 17(2): 199-215.

Kaufman C, de Wet T, Stadler J 2001. Adolescent pregnancy and parenthood in South Africa. Studies in Family Planning, 32(2): 147 - 160.

Kelly DM 1998. Teacher discourses about a young parent program: The many meanings of "Good Choices. Education and Urban Society, 30(2): $224-241$.

Key JD, Barbosa GA, Owens VJ 2001. The second chance club: Repeat adolescent pregnancy prevention with a school-based intervention. Journal of Adolescent Health, 28(3): 167-169.

Ladner JA 1987. Black teenage pregnancy: A challenge for education. Journal Negro Education, 56(1): $53-63$. 
Leach E 2000. Gender implications of development agency policies on education and training. International Journal of Education Development, 20(4): 333-347.

Lemmer E, Van Wyk N 2004. The dynamics of parents and teachers' experiences of parent involvement in a South African schools. Journal of Educational Studies, 3(1): 11 - 21 .

Lietz CA, Langer CL, Furman R 2006. Establishing trustworthiness in qualitative, research in social work: Implications from a study regarding spirituality. Qualitative Social Work, 5(4): 441456.

Lincoln YS, Guba EG 1985. Naturalistic Inquiry. Newbury Park CA: Sage Publications.

Manzini N 2001. Sexual initiation and childbearing among adolescent girls in Kwazulu Natal, South Africa. Reproductive Health Matters, 9(11): 4452 .

Mcgaha-Garnett V 2007. Teenage Parenting and High School Dropouts: Understanding Students' Academic, Social and Personal Influences. Ph.D. Disser-tation, Unpublished. Texas: Texas Tech. University.

McMillan JM, Schumacher S 2006. Research in Education: Evidence-based Inquiry. Boston: Peason Education.

Merriam SB, Associates, 2002. Case study. In: S B Marriam, Associates (Ed.): Qualitative Research in Practice: Examples for Discussion and Analysis. San Francisco: Jossey-Bass, pp. 178-180.

Meekers D, Ahmed G 1999. Pregnancy-related school dropout in Botswana. Population Studies, 53(1): $195-209$.

Miller L, Cur M, Shanok A, Weissman M 2008. Interpersonal psychotherapy with pregnant adolescents: Two pilot studies. Journal of Child Psychology and Psychiatry, 49(7): 733 - 742.

Mncube V 2007. School governance in the democratisation of education in South Africa. Is social justice on the agenda? Journal of Educational Studies: 6(1): $104-121$.

Mncube V, Harber C 2009. Learners' involvement in democratic governance of schools: A comparative study between Britain and South Africa. Journal of Educational Studies, 8(1): 33 - 56.

Moss G 2004. Provisions of trustworthiness in critical narrative research: Building inter-subjectivity and fidelity. The Qualitative Report, 9(2): 359-374.

Nyarawanda V 2003. Doing qualitative research. Zimbabwe Bulletin of Teacher Education, 12(1): $1-15$.

Panday S, Makiwane M, Ranchod C, Letsoalo T 2009. Teenage Pregnancy in South Africa with a Specific Focus on School-Going Learners. Child, Youth, Family and Social Development, Human Sciences Research Council. Pretoria: Department of Basic Education
Pandor N 2007. Address by the Minister of Education, Naledi Pandor at the National Youth Commission Conference on Young Women and Development: Johannesburg 30/08/2007: Policy.org.za, 1-4.

Richter MS, Mlambo GT 2005. Perceptions of rural teenagers on teenage pregnancy. Health $S A$ Gesondheid, 10(2): 61- 69 .

Runhare T 2010. A Comparative Case Study of Institutional Responsiveness to the Mainstreaming of Pregnant Learners in Formal Education. Ph.D. Thesis, Unpublished. Pretoria: University of Pretoria.

Sadie Y 2001. Post-Beijing initiatives by governments: A comparative assessment of South Africa and other SADC States. Agenda, 47: 65 - 74.

Smit B 2001. Atlas ti for qualitative data analysis. Perspectives in Education, 20(3): 65-75.

Smit B 2002. Atlas.ti for quality in qualitative research: A CAQDAS project. Education as Change, 6(1): $130-145$.

South African Schools Act No.84. 1996. Pretoria: Government Printer.

Stemler S 2001. An Overview of Content Analysis. Practical Assessment, Research and Evaluation. 7(17): 1 - 11. A Peer-reviewed Electronic Journal. (Retrieved July 30, 2010).

Stromquist NP 1999. Waiting for government: The implementation of legislation and gender issues in the USA. In: S Eiskine, M Wilson (Eds.): Gender Issues in International Education: Beyond Policy and Practice. New York: Falmer Press, pp. 91112.

Stromquist NP 2005. The impact of globalization on education and gender: An emergent cross- national balance. Journal of Education, 35: 7 -37.

Subrahmanian R 2005. Gender equality in education: Definitions and measurements. International Journal of Educational Development, 25(4): 395407.

Truscott K 1994. Gender in Education. Johannesburg: University of Witwatersrand and National Education Coordination Committee (NECC).

Tsanga A, Nkiwane V, Khan N, Nyanungo K 2004. Children and Women Rights in Zimbabwe: Theory and Practice. Harare: UNICEF.

Tshikhudo E 2008. Mbilwi Secondary Celebrates its Success. Mirror, $15^{\text {th }}$ February, P. 3 .

Weiner R 1987. Teen Pregnancy: Impact on the Schools: A Special Report for the Education Research Group. Alexandria: Capitol Publications.

Wolpe A, Quinlin O, Martinez L 1997. Gender Equity in Education: Report of the Gender Equity Task Team: Department of Education, South Africa, 1997. Pretoria: Department of Education.

Yin RK 1994. Case Study Research: Design and Methods. London: SAGE Publications. 